\title{
HARMONISATION OF OlD-AgE SECURITY WITHIN THE EUROPEAN UNION
}

\author{
SILKE UEBELMESSER \\ CESIFO WORKING PAPER NO. 1108 \\ CATEGORY 1: Public FinANCE \\ DECEMBER 2003
}

An electronic version of the paper may be downloaded

- from the SSRN website:

- from the CESifo website:

www.SSRN.com

www.CESifo.de 


\title{
HARMONISATION OF OLD-AgE SECURITY WITHIN THE EUROPEAN UNION
}

\begin{abstract}
Not sufficiently harmonised national pension systems within the European Union distort the allocation of labour and endanger redistributive activities. This paper identifies the most decentralised level of harmonisation which guarantees efficient allocation and enables redistribution. For this, we build on theoretical results to evaluate the realised distribution of the legal power between the European Union and the Member States and the resulting level of harmonisation. We find that harmonisation is sub-optimally low. Binding rules guaranteed by the European Union are needed which means that the Member States have to concede more fundamental responsibilities to the European Union.
\end{abstract}

JEL Classification: F22, H55, K33, N34.

Keywords: european integration, mobility, unfunded pension systems, system competition, allocation of labour, intergenerational redistribution.

\author{
Silke Uebelmesser \\ CESifo \\ (University of Munich \& Ifo Institute) \\ Poschingerstrasse 5 \\ 81679 Munich \\ Germany \\ silke.uebelmesser@ces.vwl.uni-muenchen.de
}




\title{
1. Introduction
}

\author{
Article $8 a$ of the Treaty gives every citizen of the \\ Union the right to reside freely within the territory \\ of the Member States. [...] The challenge now is \\ therefore to create a real European mobility area \\ [...] European Commission (1994, p.26)
}

In the European Union, mobility is low. Each year, only $0.2 \%$ of the population migrate to another European country (OECD, 2001) and only 1.2\% move to another European region (Gros and Hefeker, 1999). In the United States, mobility between States is about three times as high as mobility within Germany or within England and Wales (Eichengreen, 1991). With further European integration and thus lower barriers to migration, this is expected to change. But even if the total volume of migration would not increase by much, a higher degree of mobility of those individuals who contribute to the unfunded pension systems would be enough for the Member States to engage in competition. Marginal mobility is all that is needed for this to start (Sinn, 1998). Inner-European mobility is thus associated with fears that competition over mobile individuals will lead to a "race to the bottom" of old-age security.

The realisation of one of the most fundamental goals of the European Union - free mobility as part of the common internal market - has consequences for efficiency and redistribution. If mobility is not distorted due to legal or real impediments, a higher degree of mobility allows for a more efficient allocation of labour across Member States which increases national incomes and thus the resources available for redistribution. However, this is only the case if redistributive activities are sufficiently harmonised. Otherwise efficiency is not reached while, in addition, mobility reduces the scope for redistribution by putting pressure on the national fiscal systems and on the national pension systems (Sinn, 1998). These arguments make it clear that economically reasonable levels of harmonisation of the national pension systems are needed to guarantee allocative efficiency and to enable redistributive activities. ${ }^{1}$

It is especially important to avoid competition among countries in areas where the state should step in on the national level according to the "selection principle" because a market failure has been identified (Sinn, 1997, 2003). Introducing competition on the European level cannot lead to an efficient outcome if old-age security fulfils the criteria for an intervention of the state on the national level. A (rather) centralised solution is then the best. In fact, old-age

\footnotetext{
1 It is sometimes argued that migration from non-European countries might help to guarantee financial sustainability of the European pension systems in the presence of ageing. Calculations by the United Nations (2000), however, show that the migration volumes needed exceed by far the present volumes. The OECD (2001) confirms this by observing that the importance of migration with respect to reducing demographic imbalances should not be overstated. Net immigration might prevent a decrease in population for a limited time; but it certainly cannot on its own provide an answer to population ageing.
} 
security organised as unfunded pension systems involves a social contract between generations - alive and not yet born. This contract, which has been concluded on behalf of the individual by the parents or grandparents, would not have any binding effect in the private insurance market. An intervention of the state is thus necessary on the national and on the European level to guarantee the fulfilment of the social contract. ${ }^{2}$

This intervention can take place in different ways. In this paper, we identify the optimal most decentralised solution and compare it to the institutional set-up. For this we analyse the institutional distribution of competences, i.e. of the legal power to decide about pension issues, between the European Union and the Member States and the realised level of harmonisation. Harmonisation is understood as a rather general concept. On the one hand, it comprises measures which link national pension systems closer to one another. These measures are thus particularly suitable for systems which are similar in important respects. On the other hand, it includes measures which regulate the reassignment of migrants without modifying national pension systems. These measures are also well applicable to systems which show essential differences. Both types of measures will be discussed in the following.

So far, harmonisation is in the European Union sub-optimally low. Free labour mobility is ensured by the mutual recognition of pension claims by the Member States. This, however, does not remove the allocative distortions and does not prevent the erosion of redistributive activities. As will be shown, the main competences for pension systems could stay with the Member States. But the European Union must guarantee the binding nature of the respective harmonisation rules. Although the European Union has gained responsibilities in the area of social policy in the last decades, the Member States are reluctant to concede further, more fundamental rights. A more courageous approach leading to a more pronounced involvement of the European level is, however, needed.

In what follows we assume that the European Union is a closed economy and abstract from interactions with non-EU countries via, e.g., external migration flows. We focus exclusively on the first pillar of pension systems, i.e. on mandatory, publicly organised unfunded systems. In section 2, we analyse distortions of the migration decision in the absence of harmonisation of the national pension systems. Potential solutions to the problem are discussed in section 3 . For pension systems which are similar with respect to important aspect, e.g. size and generosity, section 4 analyses the optimal level of harmonisation while section 5 looks at the institutionally realised level of harmonisation. In section 6 , we evaluate the institutional findings for the allocation of labour and redistributive activities. Section 7 discusses an enlargement of the policy space for systems displaying fundamental differences e.g. originating from a Beveridgean or Bismarckian tradition, and section 8 concludes.

\footnotetext{
${ }^{2}$ We abstract here from discussing the optimality of the initial conclusion of this contract.
} 


\section{Distorted migration in the absence of harmonisation}

A simple two-country model suffices to illustrate the basic consequences of not sufficiently harmonised pension systems for efficiency and redistribution (Wildasin, 1999). Let the total population of countries $f$ and $g$ be $\bar{N}=N_{f}+N_{g}$ where we assume that all individuals in both countries work. In the absence of any public intervention, with equal goods prices and without migration costs, individuals migrate until gross wages are equal in both countries. With competitive labour markets, this implies equality of the marginal productivities of labour in both countries. The resulting allocation of labour with $N_{f}^{*}$ individuals in country $f$ and $\bar{N}-N_{f}^{*}$ individuals in country $g$ is efficient.

Now, we add activities of the public sector to our analysis where $\Gamma_{i}$ defines the difference between the benefits an individual receives and the payments an individual has to make in country $i$. If benefits are different from payments, the system creates a wedge between net wages and gross wages. In the following we abstract from other taxes and transfers and focus on possible distortions due to the unfunded pension system. This enables us to see how differently attractive unfunded pension systems influence the migration decision which implies a comparison of the present value of lifetime net income. We therefore reinterpret the static model in present-value terms thus allowing for a multi-period perspective.

For this analysis we make use of the concept of implicit taxes. When an unfunded pension system is introduced, the first, introductory generation receives pension benefits without having (much) contributed. This introductory gift generates an implicit debt which has to be serviced by the following generations via implicit taxes. The size of these implicit taxes is the difference between the present value of pension benefits and contributions and depends on the difference of the internal rate of return of the pension system and the market rate of return. If the internal rate of return falls short of the market rate of return, part of the contributions to the unfunded pension system is lost or would not be necessary if contributions were invested in the capital market. This part is called the implicit tax part $\Gamma_{i}{ }^{3}$

The internal rate of return itself depends on the productivity growth rate and the population growth rate (Aaron, 1966). As has been already mentioned, the ratio of young to old, i.e. of contributors to retirees, is essential for the sustainability and profitability of unfunded pension systems. The development of fertility, life-expectancy, and migration is thus an important determinant of the internal rate of return and of the size of the implicit taxes.

\footnotetext{
${ }^{3}$ See Sinn (2000) for explicit derivations of the implicit tax.
} 
When individuals decide about whether and where to migrate, they take lifetime net wage income into account. The lifetime net wage income an individual can earn in country $i$ is determined by the country-specific productivity as well as by the country-specific taxes implicit in the unfunded pension system. For this, we assume that the membership in the national pension systems follows the employment principle. Positive or negative implicit taxes distort the migration decision while at the same time migration and fertility influence the size of the implicit taxes. If implicit taxes differ across countries, $\Gamma_{g} \neq \Gamma_{f}$, the allocation of labour is distorted, $N_{f}^{\times} \neq N_{f}^{*}$, leading to an efficiency loss. This implies that the migration equilibrium only leads to an efficient allocation of labour if the implicit taxes are either zero, which means an abolition of the unfunded pension system, or if they are equal across countries, which corresponds to a neutralisation of the distortionary effects on the allocation of labour. The discussion in the next section will make use of these observations.

Implicit taxes are not a minor and thus negligible part of the contributions. They are large enough to effect migration decisions based on lifetime income. Wildasin (1999) has calculated implicit taxes for the pension systems of seven European countries. ${ }^{4}$ Table 1 displays implicit taxes over the life cycle of individuals of age 20 and 40 in selected European countries depending on their age and their marital status. Given the many assumptions needed to arrive at these results, the absolute values might be less informative than the relative differences across countries. What can, however, be said when looking at individual countries is that the present value of contributions falls short of the present value of pension benefits for young individuals in all countries with huge differences across countries, ranging from a loss of $3 \%$ to $31 \%$ of lifetime wealth for singles and $2 \%$ to $30 \%$ for married individuals.

It can easily be seen that implicit taxes of this magnitude might affect the decision to migrate. With the exception of the Netherlands, Germans for example who migrate to any one of the other countries reduce their implicit tax burden quite substantially. ${ }^{5}$ Depending on how sensitive migrants are with respect to these tax differences, an efficient allocation of labour is then very improbable.

\footnotetext{
${ }^{4}$ Individuals are assumed to earn the mean wage in each country, with their lifetime earning growing over time to take account of the effect of experience on wages. All individuals start working at age 20 and retire when they are entitled to receive full retirement benefits. Individuals are either single or married with a non-working spouse and no children. To simplify the analysis, spouses are assumed to die at the same age as the individual.

${ }^{5}$ The formerly centrally planned economies of Eastern and Central Europe inherited comprehensive unfunded old-age security systems (see Gern, 2002, for an overview). Pension expenditures have been high and have even increased in the early years after the transition. Reform activities have so far not led to fundamental changes. But major reforms including shifts towards more funding are now intensively discussed in several countries. Depending on whether these reforms will succeed in reducing the implicit taxes, the decision whether to migrate after accession and where to go will be affected and the allocation of labour will thus be distorted.
} 
Table 1: Implicit taxes by age and marital status (in Euros and as a percentage of lifetime wealth)

\begin{tabular}{|l|rllr|}
\hline Country & \multicolumn{1}{l}{$\begin{array}{l}\text { Single } \\
\text { age 20 }\end{array}$} & $\begin{array}{l}\text { Married } \\
\text { age 20 }\end{array}$ & $\begin{array}{l}\text { Single } \\
\text { age } 40\end{array}$ & \multicolumn{1}{l}{ Married } \\
& $-30,152$ & $-28,224$ & $-20,240$ & $-15,503$ \\
Belgium & $-13 \%$ & $-12 \%$ & $-8 \%$ & $-6 \%$ \\
& $-11,438$ & $-7,289$ & $-3,707$ & 6,701 \\
Genmark & $-3 \%$ & $-2 \%$ & $-1 \%$ & $2 \%$ \\
France & $-53,059$ & $-53,059$ & $-38,758$ & $-38,758$ \\
& $-16 \%$ & $-16 \%$ & $-11 \%$ & $-11 \%$ \\
Italy & $-13,634$ & $-9,652$ & 15,558 & 24,786 \\
& $-6 \%$ & $-4 \%$ & $8 \%$ & $12 \%$ \\
Luxembourg & $-28,698$ & $-28,698$ & 18,173 & 18,173 \\
& $-13 \%$ & $-13 \%$ & $9 \%$ & $9 \%$ \\
Netherlands & $-33,543$ & $-33,543$ & $-15,939$ & $-15,939$ \\
& $-11 \%$ & $-11 \%$ & $-5 \%$ & $-5 \%$ \\
& $-91,018$ & $-87,810$ & $-84,439$ & $-76,772$ \\
& $-31 \%$ & $-30 \%$ & $-28 \%$ & $-25 \%$ \\
\hline
\end{tabular}

Source: Wildasin $(1999, \mathrm{p} .265)$

Legend: Calculations for contribution rates and pension formulae operative in 1986 for countries with comparable data of contributions and benefits

In the following, we assume a fixed-benefit pension system. Thus, demographic changes only affect the working generations, but not the retirees. If due to ageing in the form of higher lifeexpectancy the implicit taxes increase in country $f$, this induces individuals to emigrate; but fewer people in country $f$ lead to lower contributions to the pension system. To balance the pension budget, country $f$ must either raise the contribution rate or lower the pension benefits or both. Both increases the implicit taxes even further inducing even more migration. This shows that a country with a pension system with a highly negative implicit tax experiences emigration while a country with a less negative implicit tax is characterised by immigration. Without any form of harmonisation, these migration trends reinforce themselves. Countries then face incentives to reduce contribution rates in the first place in order to initiate this migration process in their favour. Countries which want to avoid that migration happens at their expense follow. But neither of them takes the externalities into account which they exert mutually. In the end, we can observe a "race to the bottom" with respect to old-age security.

This illustrates the potential trade-off between allocative and distributive objectives. It is therefore necessary to choose a level of harmonisation which neutralises the effect of implicit taxes and thus allows undistorted migration without the complete erosion of redistribution. 


\section{Policy options}

Efficiency requires that marginal productivities, i.e. gross wages, are equal across countries. The migration equilibrium, which equalises net wages, leads to an efficient allocation of labour if and only if (implicit) taxes are equal in both countries. The problem to be solved is to determine for all relevant migration scenarios the level of harmonisation that leads to equalised implicit taxes. All distortions of the migration decision due to implicit taxes are then neutralised and an efficient allocation of labour can be realised. For this to be achieved, the policy variables are the country-specific contribution rates. Contribution rates must be set to balance differences in the population growth rates due to fertility differences after migration.

There are several ways how to neutralise the effect of implicit taxes on the migration decision. One option would be the complete elimination of national pension systems which would also eliminate the distortions of the migration decision due to implicit taxes. The partial or complete abolition of an existing unfunded pension system or equivalently the transition to a funded pension system is, however, not Pareto-improving if there are no idiosyncratic and static inefficiencies which originate from the unfunded pension system. ${ }^{6}$ It is not possible to find an abolition or transition path which makes all generations better off. Either the old generations loose their pension benefits or the young have to contribute without acquiring own claims or both.

The mix of funded and unfunded elements in the pension system can therefore not be judged on the basis of efficiency, but is essentially a matter of intergenerational fairness. For the question of interest here this can be operationalised by looking at the documents which constitute the European Union and its preceding organisations. Although there is no explicit statement concerning national old-age security systems, it is possible to find indirect indications. "The raising of the standard of living and quality of life" for all generations has been a priority for the Member States since the very beginning (Art.2 ToR ${ }^{7}$ ). ${ }^{8}$ Starting from this statement, there has been a growing conviction concerning the importance of social policy for ensuring a high and equal standard of living over the last decades. ${ }^{9}$ The economic objective of the European Union has thus been complemented by social objectives. ${ }^{10}$ Following this evolution of social policy issues and the underlying will of the Member States, we will therefore abstract from considering the abolition of national pension systems.

\footnotetext{
${ }^{6}$ See Breyer (1989), Fenge (1995) and others.

${ }^{7}$ Treaty of Rome (1958). The dates refer to the year where the Treaty was ratified.

${ }^{8}$ See also the Preamble to the Treaty of Rome.

${ }^{9}$ For a more extensive historical overview see Uebelmesser (2003).

${ }^{10}$ For a more extensive discussion see Atkinson (1995) and Kolmar (1999).
} 
If elimination is not an option, identifying and realising the optimal level of harmonisation becomes an issue. The effect of implicit taxes on migration within the European Union would vanish with a single centralised European pension system. Migration from one European country to another would no longer imply a move from one national pension system to another and the migration decision would thus be undistorted. This is, however, a rather extreme solution given the independent history of the national European pension systems.

Starting from complete centralisation, we therefore want to identify the most decentralised structure which allows achieving an efficient allocation of labour without initiating a collapse of intergenerational redistribution (Breyer and Kolmar, 2002). There are several levels of harmonisation which have to be considered. Co-ordination or equalisation of contribution rates leads to a strong link between national pension systems. In such a system, an absolute level which contribution rates may neither exceed nor undercut might be defined or a relative level in relation to other countries' contribution rates. For the special case where contribution rates are equal across countries, the national pension systems are called equalised. A weaker form of harmonisation is the mutual recognition of pension benefits. ${ }^{11}$ National pension systems without any form of harmonisation are called decentralised.

It is evident that linking pension systems by harmonising their contribution rates and/or benefit levels is difficult if this means to reconcile very different levels of size and generosity as well as very different revenue structures. Despite some convergence of old-age security originating from the Beveridgean or Bismarckian tradition, public pension systems still display some differences with respect to their aim and scope. Pension systems are also difficult to harmonise if the source of revenue is different consisting predominately either of contributions or taxes. In all those cases, the level of redistribution which results from harmonising need not equal the level of redistribution most preferred by the majority of the Member States. In the following, we assume that the national pension systems are sufficiently similar. Options, which are particularly suitable for old-age security systems with significant differences, are analysed in section 7.

\section{Optimal level of harmonisation}

We assume that membership in the national pension systems is according to the employment principle and abstract for now from the possibility of interjurisdictional transfers and individual payments. For this restricted policy space, we determine the minimum degree of harmonisation necessary and sufficient for efficient allocation of labour and intergenerational

\footnotetext{
11 Examples for this are the exportability of benefits and the conversion of insurances periods. See the regulations $1408 / 71$ and $574 / 72$ for the details.
} 
redistribution given different degrees of mobility. We then use this as a benchmark to evaluate the realised level of harmonisation.

As a benchmark, we first look at the case of unrestricted mobility in all periods. ${ }^{12}$ The final goal of the European Union is the realisation of the four liberties - among them the free movement of labour. Barriers to mobility are consequently dismantled which leads to a reduction of mobility costs. This development will allow efficient allocation of labour but endangers the financial sustainability of the social security systems making redistribution difficult.

Breyer and Kolmar (2002) show on the basis of the results by Homburg and Richter (1993) that for this restricted policy space considered here ${ }^{13}$ the equalisation of contribution rates is sufficient and necessary for an efficient allocation of labour even with different fertility rates.

As has already been pointed out, differences in implicit taxes across countries lead to distortions of the migration decision. The burden depends in particular on the country-specific contribution rates and the population and productivity growth rates relative to the market rate of return. ${ }^{14}$ With productivity growth rates assumed to be zero, the contribution rates are choice variables of the government, while the population growth rates are choice variables of the present and the future generations. In a steady-state equilibrium with perfect foresight, the differences in fertility rates are eliminated by (unrestricted) migration if the national pension systems do not lead to additional incentives to migrate due to differences in contribution rates. Consequently, an efficient migration equilibrium requires that contribution rates have to be equalised - either at a positive level or at the level of zero. It is then optimal to migrate until fertility rates are equal as it is consistent to believe that the members of the next generation will behave identically. Centralisation is thus not required.

The case of unrestricted mobility is helpful - though in sharp contrast to European reality. In order to draw conclusions for the optimal level of harmonisation, it is useful to focus on two cases which reflect the most probable scenarios for the European Union: restricted mobility today and either unrestricted mobility or restricted mobility in the future. As we will see, the degree of mobility in the future determines the minimum requirements of harmonisation for an efficient allocation of labour.

Case I: Restricted mobility today and unrestricted mobility in the future:

For unrestricted mobility from period $t+1$ onwards, we know from the analysis above that an efficient allocation of labour requires equal contribution rates. It must only be verified

\footnotetext{
12 The terms "unrestricted" and "restricted" refer to the part of the population for which mobility costs are low enough. They do not imply that there are any restrictions due to interventions from the government.

${ }^{13}$ Note that we abstract here from the possibility of interjurisdictional transfers and individual payments.

${ }^{14}$ See Sinn (2000) for more details.
} 
whether equal contribution rates are compatible with efficiency from period $t$ on. Breyer and Kolmar (2002) show that this is in fact the case. As a result, an equalisation of contribution rates is the minimum level of harmonisation which leads to an efficient allocation of labour.

Case II: Restricted mobility today and in all future periods:

With restricted mobility in all periods, we have to distinguish three cases concerning the degree of mobility from periods $t+1$ onwards (Breyer and Kolmar, 2002). For the minimum level of harmonisation, the size of the mobile group relative to the differences in the fertility rate is essential. The reason for this is that the implicit taxes in both countries depend on the growth rates of the population after migration has taken place.

If the mobile group is big enough to compensate for the fertility differences, the population distribution can converge over time (Case IIa). There exists some period $t^{*}$ from which on the population growth rate in both countries will be identical. This brings us back to the results for unrestricted mobility. Equal contribution rates are then necessary and sufficient for an efficient allocation of labour in all periods.

If the mobile group is, however, not big enough to balance the fertility difference, two further cases have to be distinguished. First, mobility is large enough so that the fertility difference can be compensated and the population distribution between the two countries will be stabilised on the initial level (Case IIb). Second, mobility is too small. The population distribution will further diverge (Case IIc). Since in these two cases the growth rate of the population cannot be equalised by migration, equal contribution rates in both countries would not lead to a neutralisation of the country-specific implicit taxes. Breyer and Kolmar (2002) show that for these cases co-ordinated contribution rates are necessary and sufficient for efficiency, i.e. the contribution rates must be set in a specific ratio to one another which depends on the country-specific population growth rates.

No matter how long the time horizon, Wildasin (2000) expects mobility to increase but does not consider perfect mobility to be a realistic scenario. The projections of Eurostat (2000) confirm this view. The total volume of net migration to countries of the European Union will even slightly decrease in the next 50 years from a total of 661,000 in 2000 to 622,000 in 2050 . Even though it can be assumed that intra-EU migration will be more important in the next few decades at the cost of immigration from non-EU countries, the numbers indicate that mobility will be far from 100\%. To increase mobility, the European Commission (1996) has identified the following areas as requiring in particular further effort: Mutual recognition or harmonisation of professional degrees and harmonisation of the tax systems and the social security systems including pension systems. A common language - though very unlikely to be 
agreed upon - would also reduce migration costs. Although there is some progress, it will be difficult to completely remove the most important barriers to migration.

To sum up, if we characterise the present situation in the European Union with respect to migration as one with restricted mobility, there are two relevant scenarios to distinguish. First, mobility could be equally restricted in the next periods. Second, mobility could increase and become (close to) unrestricted. For both cases, a co-ordination or equalisation of contribution rates across countries is necessary and sufficient for efficiency. Centralisation of national pension systems in the form of a unified European pension system is not required. We now analyse the institutional setting of the European Union to compare the optimal level of harmonisation to the realised one.

\title{
5. Realised level of harmonisation
}

The historical evolution of the European Union as briefly discussed above shows that social policy as a by-product of economic policy or as an independent objective to complement economic integration are both anchored in the understanding of the European Union.

The measures of the European Community, which concern in particular old-age security, are limited to regulations of the mutual recognition of pension claims without linking old-age security systems any closer. Art.48 ToR $\left(39 \mathrm{ECT}^{15}\right)$ states explicitly that the freedom of movement for workers has to be secured by "abolition of any discrimination based on nationality" while Art.8a ToR (18 ECT) extends the right of free movement to every citizen of the European Union. Art.49 ToR (40 ECT) regulates the abolition of administrative obstacles in general. Art.51 ToR (42 ECT) mentions measures necessary to provide freedom of movement in the field of social security. In particular, it states that

\begin{abstract}
The Council shall [...] make arrangements to secure for migrant workers and their dependants: (a) aggregation, for the purpose of acquiring and retaining the right to benefit and of calculating the amount of benefit, of all periods taken into account under the laws of the several countries; (b) payment of benefits to persons resident in the territories of Member States.
\end{abstract}

Old-age security is thus a relevant issue for the European Union in the sense that a lack of harmonisation endangers the free movement of workers. In particular, the acquisition of pension claims and the payment of pension benefits must be secured for migrant workers. The details can be found in regulation 1408/71 and (implementing) regulation 574/72. Both define

\footnotetext{
${ }^{15}$ Treaty of the European Community (1993).
} 
procedures concerning the recognition of pension claims of migrant workers such that migrants and non-migrants have to be treated equally.

Over the last decades, the awareness for social policy issues at the European level independent from economic considerations, which has been accompanied by the proEuropean position of the European Court of Justice, ${ }^{16}$ has increased - though not always continuously. Social policy issues are no longer reduced to supporting the evolution of the common market, but are more and more regarded as an objective in itself. Correspondingly the competences of the European Community have been extended including legislative authority in the area of social policy since the Treaty of Amsterdam (1999).

This gives grounds to think that the competences of the European Community have been unambiguously extended to social policy issues which have previously been in the responsibility of the Member States; and that this process is going to continue with consequences for the level of harmonisation. In order to be able to evaluate whether this impression is correct, we look in more detail at the distribution of competences as far as the national pension systems are concerned. Competences can be seen as a means to the end of a certain level of harmonisation. Knowledge of the distribution of competences therefore helps to understand the observed level of harmonisation.

The question is whether the competences which would be needed to establish the optimal level of harmonisation have already been transferred to the European level. For the most realistic migration scenarios, we have seen that equalisation or co-ordination of contribution rates is needed to guarantee the efficient allocation of labour and to avoid an erosion of intergenerationally redistributive activities

\subsection{Distribution of competences}

The realisation of European integration has been concerned with the creation of the Economic Union on the basis of the four freedoms of movement. It has not been a primary goal to appropriate social policy competences from the Member States (Breyer and Kolmar, 1996). The competences for social policy are thus principally located at the national level. The European institutions lack the legal basis to intervene, e.g., in the nationally organised old-age security systems. From the legal perspective, the territorial principle applies to all areas of social policy, i.e. the Member States are responsible for social issues in their territory. In the

\footnotetext{
${ }^{16}$ See in particular Judgement of the Court of 21 October 1975, case 24/75 (Petroni), European Court reports, 1975; Judgement of the Court of 5 July 1967, case 1/67, (Ciechelski), European Court reports, 1967, section 2; Judgement of the Court of 14 March 1989, case 1/88 (Baldi), European Court reports, 1989, section 22.
} 
case of old-age security, the territory principle corresponds to the employment principle which implies that the membership in a national pension system is determined by the place of employment.

This principle, however, is limited if free mobility of labour (Art.39 ECT) is endangered. Legislative activities at the European level can then be justified - at least if they are in accordance with the principle of subsidiarity as stated in Art.5 ECT

[...] In areas which do not fall within its exclusive competence, the Community shall take action, in accordance with the principle of subsidiarity, only if and insofar as the objectives of the proposed action cannot be sufficiently achieved by the Member States and can therefore, by reason of the scale or effects of the proposed action, be better achieved by the Community. [... $]^{17}$

Art.5 thus regulates in which areas the European Community may act if this is deemed necessary including areas not specifically mentioned in the Treaty. But this is restricted to instances where the subsidiarity principle is not violated and where the actions of the European Community can be justified by the objectives of the Treaty. The additional competences which can be derived for the European level are thus limited by the subsidiarity principle.

The question is, however, whether these limitations are in any way binding, or to say it differently, how strict the principle of subsidiarity is interpreted. In general, Eichenhofer (2002) considers the principle of subsidiarity as not very effective to protect the competences of the Member States.

As far as pension issues are concerned, however, the Council can only act unanimously on a proposal from the Commission after consulting the European Parliament and the Economic and Social Committee (Art.137 (3) ECT). Social security issues thus require unanimity of the Council. This implies that the Member States have veto power or "ultimate sovereignty". ${ }^{18}$

In general, the de facto distribution of competences is not very clear. ${ }^{19}$ Given the high degree of interaction between economic integration and social policy issues, the fields of social policy which are related to the freedom of movement and other aspects of the common

\footnotetext{
${ }^{17}$ See also Art.2 EUT which explicitly refers to Art.5 ECT.

${ }^{18}$ In other areas, this is no longer the case. Question concerning, for example, the equality between men and women, working conditions, etc., the Council may adopt directives by a qualified majority under the co-decision procedure after consulting the Economic and Social Committee and the Committee of the Regions (Art.251 ECT).

${ }^{19}$ The so-called Post-Nice Process is supposed to clarify this by 2004. A more concrete definition of European and national competences as well as the role of national parliaments within the European Union is part of the agenda.
} 
internal market are numerous. Alone the economic importance of old-age security would suffice to justify the competences of the European Community in this area. For many social policy issues, the competences are already shared between the European Community and the Member States with the centre of gravity shifting more and more to the European level as the integration process advances. However, concerning pension issues, the main competences still remain with the Member States - either because of their specific responsibilities in this area or because of their veto power. This is of course not without consequences for the level of harmonisation.

\subsection{Impact on the level of harmonisation}

We have analysed the optimal level of harmonisation which guarantees an efficient allocation of labour without a complete erosion of intergenerational redistribution. For the realistic cases of restricted mobility today and restricted or unrestricted mobility in the future, co-ordination or equalisation of the contribution rates leads to optimal results. We now want to see what impact the distribution of competences between the Member States and the European Community has on the level of harmonisation and compare the outcome with the optimal level. It is useful to look at the competences and the resulting level of harmonisation separately for activities which support the economic and social objectives.

We begin with actions of the European Community within the framework of the economic objectives. The measures which are intended to reduce the obstacles to free movement of labour support the mutual recognition of pension claims. It is possible for the European Community to demand from Member States to recognise pension claims acquired in other Member States in order to ensure that workers and members of their families exercising their right of free movement do not suffer negative consequences with regard to their pension benefits. $^{20}$

And which level of harmonisation results from the increase in competences within the Social Union? The legislative authority of the European Community in the social area is described in Art.136 and 137 ECT. Although the objective of supporting the social development in various areas is reaffirmed, it is emphasised that "[...] the Community and the Member States shall implement measures which take account of the diverse forms of national practices [...]" (Art.136 (2)). It is required that "the Council may adopt [...] minimum requirements for gradual implementation, having regard to the conditions and technical rules obtaining in each of the Member States" (Art.137 (2)). This is concretised as "excluding any harmonisation of the laws and regulations of the Member States" (Art.137 (4)).

\footnotetext{
${ }^{20}$ See Art.42 ECT and regulations $1408 / 71$ and 574/72.
} 
With regard to the national social security systems, Art.137 (4) more specifically states that

\begin{abstract}
[t] he provisions adopted [...] shall not affect the right of Member States to define the fundamental principles of their social security systems and must not significantly affect the financial equilibrium thereof [...].
\end{abstract}

Especially the last point underlines, that the European Community is not entitled to appropriate in any way the responsibility of the Member States for the national pension systems. Concerning the harmonisation efforts, the legislative authority of the European Community seems to be restricted to those measures which reduce the obstacles to free movement of labour. As we have already observed, the level of harmonisation - limited to the mutual recognition of pension claims - is low. Although the general competences of the European Community have been extended to instances where "measures of the Member States or no measures at all violate the requirements of the Treaty, e.g., with respect to economic and social integration" (Protocol No 30, 1997), the concrete provisions are limited to the adoption of "minimum requirements for gradual implementation" (Art.137 (2)). The economic objectives are thus (still) the driving force for the harmonisation efforts and not the social objectives.

\title{
6. Evaluation of the institutional results
}

After having analysed the theoretically optimal and the institutionally realised level of harmonisation, we now turn to compare both results. As Breyer and Kolmar (1996) point out, ,[i]t is not the level of social transfers per se, but the organisational structure that might be responsible for the non-achievement of maximum gross national products" (p.148f). The focus will therefore be on the impact of the realised institutional structure on the efficient allocation of labour and the level of redistribution.

\subsection{Allocation of labour}

Two aspects have to be distinguished. The first one concerns the question whether all obstacles have been removed so that free movement is possible within the European Union. The second one deals with efficiency asking whether mobility is distorted.

As we have seen, countries of the European Union are obliged to mutually recognise pension claims acquired in other Member States (Art.42 ECT). Migrating from one country to another country is not impeded by losing pension benefits. Individuals will thus migrate to countries where their labour income over the life-cycle net of explicit and implicit taxes is maximal. If we abstract from differences in explicit taxes and restrict our attention to old-age security, the 
choice of the destination country will then be determined by differences in gross wages, i.e. in marginal productivities if we assume complete labour markets, and differences in the taxes implicit in the national pension systems. While migration that equates gross wages results in an optimal allocation of labour, this is not the case for migration that leads to equal wages net of implicit taxes - if implicit taxes differ across countries. The analysis of the institutional regulations of the European Union has shown that equalising and thus neutralising implicit taxes is not an explicit goal of the process of convergence. A reduction of the distortions due to different implicit tax burdens could only emerge as an accidental by-product.

The European Court of Justice more explicitly influences migration when interpreting the regulations 1408/71 and 574/72 in a pro-migration way. In fact, the European Court of Justice has to rule in accordance with the European Treaties which explicitly put forward the objective to support the process of European integration. The Court assumes implicitly that intra-European migration promotes integration. The question is, however, whether the decisions of the Court with respect to migration stimulate a sub-optimal level of migration in the sense of too much migration. Positively discriminating migrants compared to nonmigrants might lead to distortions of the optimal allocation of labour. The economic objective and the objective of the Court differ concerning migration; potentially inefficient migration might be encouraged or even intensified.

National pension systems do not present important obstacles to migration. The principle of mutual recognition ensures that the free movement of labour is not hindered. Measures which guarantee that migration is undistorted are, however, absent. Neither the national countries nor the European institutions seem to be aware of the distortions of the allocation of labour which stem from implicit taxes - as well as from explicit taxes. The regulations concerning the free movement ignore the presence of distortions and the Court does not use its authority to create the preconditions for an efficient allocation of labour.

\subsection{Level of redistribution}

Despite the increase in competences of the European Community for social policy issues, the responsibility for the organisation of the national pension systems stays with the Member States. Only when the functioning of the common market in general and the free movement of labour in particular are endangered has the European Union the right to intervene. To guarantee that mobility is not impeded by incompatibilities of the national pension systems, Member States must mutually recognise pension claims.

All initiatives to harmonise the national pension systems further - e.g. in the form of coordinated or equalised contribution rates - are based on a process of convergence in the 
medium-term via the identification and realisation of best practices and depend on the voluntary agreements of the Member States. This process thus lacks the binding character necessary to avoid a "race to the bottom" of intergenerationally redistributive activities even though the European Community has the legislative authority to transform the results of the convergence process into binding laws (Eichenhofer, 2002). But it must be doubted whether the Member States will agree on the harmonisation of fundamental aspects of the national pension systems as, e.g., the contribution rate. If they do not, i.e. if pension systems remain decentralised, a merely voluntary commitment not to engage in a "race to the bottom" is not credible. $^{21}$

\subsection{Consequences}

For the restricted policy space, the analysis so far has shown that the approach towards harmonisation of national pension systems as chosen by the European Union neither leads to an efficient allocation of labour nor prevents a "race to the bottom" of intergenerational redistribution. So, how should the competences be optimally distributed to achieve these objectives given the restricted policy space?

To answer this question, let us turn again to the principle of subsidiarity. In the context of the distribution of competences between the Member States and the European Community, subsidiarity indicates that the responsibility should be with the lowest level which can fulfil the task in the best way. For the economic application of the subsidiarity principle with respect to old-age security, the existence and the range of (fiscal) externalities need to be determined. The political decision-making should then be allocated to the level at which an internalisation can be best guaranteed and an efficient allocation of labour and intergenerational redistribution can be reached (Krieger, 2001).

The main features of pension systems are that they redistribute incomes across generations and within generations from individuals with bad luck as to longevity to individuals with good luck (Kolmar, 1997). The ex post enforcement of the contract is, however, not possible in the context of the employment principle. The net contributors, i.e. the young or those who have information indicating that their life-expectancy is below average, can escape by migrating. This makes it clear that a more pronounced involvement of the European level is needed.

This result is nothing else than an application of the "selection principle" (Sinn, 1997, 2003). If, as we have seen, old-age security fulfils the criteria for an intervention of the state at the

\footnotetext{
${ }^{21}$ Breyer and Kolmar (2002) show that the co-ordination requirements are incompatible with voluntary coordination of the Member States. If every country maximises national welfare without taking into account the external effects on other countries, a unilateral deviation is profitable.
} 
national level according to the "selection principle", introducing competition on the European level cannot lead to an efficient outcome. Even though the main competences for old-age security can stay with the Member States, the necessary responsibilities must be conceded to the European Union to allow an effective monitoring of the harmonisation rules.

It has been realised that a higher level of harmonisation is needed in various areas of social policy including old-age security; and that a closer cooperation is useful given the similar challenges which the national pension systems have to face. So far, we have analysed the impact of increased labour mobility on unfunded pensions systems which are very similar with respect to important aspects, e.g. size and generosity. But it is evident that different views on how to organise old-age security coexist in Europe given the distinct histories of social security systems in each Member State. In some circumstances, harmonisation becomes very demanding if not impossible. In the next section, we therefore discuss solutions which might be less controversial and which can be applied to unfunded pension systems which differ with respect to their aim and scope.

\section{Extensions}

We now include transfers and payments among the available measures thus enlarging the policy space. We also look at the case where migration does not at all affect the membership in a pension system (home-country principle) or only with a delay of several years (principle of delayed integration). Migration then no longer implies the immediate change from the pension system of the country of origin to the pension system of the destination country according to the employment principle.

\subsection{Transfers and individual payments}

For the moment, we maintain the assumption that membership in pension systems follows the employment principle and discuss other options which lead to an efficient allocation of labour without a complete erosion of redistributive activities

A direct way to attack the problem of externalities of migration on national pension systems is to internalise these effects via interjurisdictional transfers (Kolmar, 1997). If changes in the pension system of one country cause external effects in other countries, the responsible country has to pay transfers to compensate the other countries. As can be shown (Breyer and Kolmar, 2002) only compulsory transfers work. In addition, it must be assumed that the information problem can be solved and that the interjurisdictional contracts are renegotiation proof. 
It is also possible to shift the responsibility for the transfers from the interjurisdictional level, i.e. the country, to the individual. Externalities on the pension systems of the source country and/or the destination country due to migration can then be internalised via payments from the individual. Depending on the direction of the external effects of the migration decision, an exit or an entry fee could be constructed.

For interjurisdictional transfers and individual payments, the requirements are much less demanding than for the case discussed above with the harmonisation of national pension systems in the form of equalisation or co-ordination of contribution rates. As these transfers and payments do not affect the general structure of the national pension systems, old-age security systems remain more independent from one another. It is therefore no longer necessary that they are similar in important aspects. In contrast, externalities due to migration can be internalised no matter how different the pension systems are.

It is evident that with 15 Member States at the moment and 10 more Member States from 2004 on, bilateral bargaining would prove to be a very complicated and complex issue. A central authority would therefore be needed for setting the transfers and payments, coordinating the redistribution of income across countries and controlling the compliance (Wildasin 1991, 1994). So even with this very much decentralised option, the Member States would be required to concede the necessary - albeit smaller - responsibilities to the European level.

\subsection{Home-country principle and delayed integration}

The inefficiencies with respect to the allocation of labour and the danger of a complete erosion of redistributive activities stem from the opportunity of individuals to opt out of an existing social contract after the individual risk is realised. Abolishing this option would remove the incentives to do so.

To avoid distortions of the migration decision due to taxes implicit in social security systems, Sinn (1990) proposes to replace the employment principle by the home-country principle. Individuals choose a social security system of one Member State once for their entire life. Then, migrating does no longer help to escape the system; especially the implicit taxes of the chosen pension system cannot be avoided by changing the place of employment. The externalities of migration on the national pension systems are completely internalised. The migration decision is thus not affected by differences of the pension burden between countries, but depends on the difference in gross wages. An efficient allocation of labour results.

Replacing the employment principle by the home-country principle eliminates any form of fiscal competition. In this respect the home-country principle is comparable to a close linking 
of pension systems. Whether less competition should be preferred to more competition or vice versa depends on what one thinks about the general operation of unfunded public pension systems (Oates, 2001, 2002). We thus enlarge the analysis by taking political economy arguments into account. If we assume that those responsible for the national pension systems seek to promote social welfare, the home-country principle is the best solution. If, however, we adhere to the Leviathan belief and assume that national pension systems are dominated by the interplay of special interest groups, the evaluation of the home-country principle is less positive.

In the specific context of unfunded pension systems, those who determine the fundamental parameters of old-age security are for the main part the voters. The home-country principle, therefore, bears the risk that the young - once they have opted for a certain national pension system - can be more easily exploited by the old in a gerontocracy. The young can counterbalance the power of the old - even when they no longer have the political majority - if they have the option to decrease their domestic labour supply, e.g., by emigrating. ${ }^{22}$ Depriving them of the option to escape the system reduces their possibilities to react to even higher pension burdens shifted to them from the old. There is thus a trade-off between too much migration motivated by the employment principle which endangers the financial sustainability of the national pension systems, and too few outside options due to the home-country principle. Although this problem concerns intergenerational redistribution and not efficiency, it is necessary to take it into account when thinking about putting the home-country principle into practice.

If fiscal competition is welcome in order to counter-balance gerontocratic tendencies, the employment principle should be advocated. If fiscal competition is, however, seen as endangering the efficient allocation of labour, the home-country principle should be chosen. But both alternative principles present rather extreme ways of how to assign migrants to jurisdictions. It has therefore been proposed to opt for a middle course with the principle of delayed integration (Sinn, 2002, and Richter, 2002). ${ }^{23}$ This principle means that migrating from one country to another country results in the assignment to the fiscal and social systems of the destination country with some delay. The principle is closer to the employment principle for a shorter delay and more similar to the home-country principle for a longer delay. Thus, the two essential aspects - distortions of labour allocation and containment of gerontocratic tendencies - are both taken into account to a certain extent. Compared to the employment principle differences in national pension systems which result in different implicit taxes do not distort the migration decision for short-term migration and play a smaller

\footnotetext{
${ }^{22}$ See Thum and Uebelmesser (2003).

${ }^{23}$ See also the report of the Council of Advisors of the German Ministry of Finance (Wissenschaftlicher Beirat, 2001).
} 
role for long-term migration. At the same time, the reassignment of migrants to the pension system of the destination country - even though with some delay - works as a counterbalance to potential gerontocratic or Leviathan tendencies.

Once more, a central authority would be needed for setting the exact rules and controlling the compliance. The Member States would again have to concede some responsibilities to the European level.

\section{Conclusion}

Although for all three options discussed - harmonisation, transfers and payments and delayed integration - competences have to be shifted from the Member States to the European Union, the extent to which the Member States would have to restrict their responsibility for old-age security is different.

The requirements for equalising or co-ordinating contribution rates are by far the most demanding. First, national pension systems must display similarities in the most important aspects and second, the Member States must be willing to forgo fundamental decision-making powers. Even though, the national pension systems have already converged to a certain extent during the last decades as a reaction to exogenous factors, fundamental differences still exist especially with respect to systems organised as "flat-rate benefit" systems in the tradition of Beveridge and "social insurance type" systems in the tradition of Bismarck. Beside, the analysis of the institutional development has shown that the Member States are still far away from approving the necessary shift of competences to the European level where the national pension systems are concerned.

Transfers and payments as well as a change from the employment principle to the principle of delayed integration have therefore some merits. First, as the national pension systems remain rather independent from one another, differences with respect to size and generosity do not present important obstacles. Second, although these options also require that the Member States concede some responsibilities to the European level, the scope is nevertheless much more reduced.

To sum up, the relation between migration and national pension systems must be considered when thinking about a reform of old-age security in the European Union. Not sufficiently harmonised national pension systems within the European Union distort the allocation of labour and endanger redistributive activities. As we have seen, it is not necessary to require that national pension systems are replaced by a uniform European pension system in order to cure both problems. The main responsibility can stay with the Member States; but the 
European Union must be involved sufficiently to guarantee the binding nature of the harmonisation rules.

If the Member States fail to agree on the role of the European Union, it is well possible that the demographic pressure on the national pension systems induces the Member States to fall back on either or both of two strategies: first, to set a "race to the bottom" in motion to attract contributors and second, to erect obstacles to prevent contributors from emigrating. As this development would be the exact opposite of the objectives of the European Union, it is very important to start with reforms as soon as possible. The European Council has realised this and initiated the process of the "open method of co-ordination" at the Lisbon Summit in 2000. But convergence based on the exchange of information in order to initiate a process of adapting common national social policies (European Council, 2000) is not able to avoid competition among the pension systems of the Member States. It must be hoped that the open method is only the first step towards a more courageous approach leading to a more pronounced involvement of the European level in the area of old-age security.

\section{Acknowledgment}

I would like to thank Claudio Thum, the participants of the CESifo Conference on "Migration and the Welfare State" and in particular Assaf Razin for their comments as well as Christina Rölz and Jesko Ullrich for discussions of the legal details.

\section{Reference}

Aaron, Henry (1966): "The Social Insurance Paradox", Canadian Journal of Economics and Political Science 32, 371-374.

Atkinson, Anthony B. (1995): Incomes and the Welfare State, Cambridge University Press: Cambridge.

Breyer, Friedrich (1989): “On the Intergenerational Pareto Efficiency of Pay-as-you-go Financed Pension Systems", Journal of Institution and Theoretical Economics 145, 643658.

Breyer, Friedrich and Martin Kolmar (1996): "Social Policy in a Common Market: Labour Market, Social Arbitrage, and Public Finance“, in Holzmann, Robert (ed.): Maastricht: Monetary Constitution without a Fiscal Constitution?, Nemos: BadenBaden.

Breyer, Friedrich and Martin Kolmar (2002): “Are National Pension Systems Efficient if Labor is (Im)perfectly Mobile?”, Journal of Public Economics 83, 347-374.

Eichengreen, Barry (1991): Is Europe an Optimum Currency Area?, NBER Working Paper 3579, Cambridge, MA. 
Eichenhofer, Eberhard (2002): "Der aktuelle Stand der europäischen Sozialpolitik", Deutsche Rentenversicherung 6, 322-331.

European Commission (1994): European Social Policy - a Way Forward for the Union (White Paper), KOM(94) 333, Brussels.

European Commission (1996): Education - Training - Research: the obstacles to transnational mobility (Green Paper), $\operatorname{KOM(96)~462,~Brussels.~}$

European Council (2000): Presidency Conclusions - Lisbon, http://ue.eu.int/ (12.11.2002).

Eurostat (2000): Revised Long-term National Population Scenarios for the European Union, Final report prepared by Statistics Netherlands: Luxembourg and Brussels.

Fenge, Robert (1995): "Pareto-efficiency of the Pay-as-you-go Pension System with Intragenerational Fairness", FinanzArchiv 52, 357-363.

Gern, Klaus-Jürgen (2002): "Recent Developments in Old Age Pension Systems: An International Overview", in: Martin Feldstein and Horst Siebert (eds.): Social Security Pension Reform in Europe, The University of Chicago Press: Chicago and London, 439-478.

Gros, Daniel and Carsten Hefeker (1999): "Factor Mobility, European Integration and Unemployment", in EC/DGV - OECD/DEELSA Seminar: Wages and Employment, European Commission: Brussels, 125-146.

Keller, Christian (2000): Die Zukunft der gesetzlichen Rentensysteme in der Europäischen Union, Institut für Wirtschaftspolitik an der Universität zu Köln: Cologne.

Kolmar, Martin (1997): On the Efficiency of National Social Security Systems in the European Union, EIB Papers 2, Luxembourg.

Kolmar, Martin (1999): Optimale Ansiedlung sozialpolitischer Entscheidungskompetenzen in der Europäischen Union, Beiträge zur Finanzwissenschaft 7, J.C.B. Mohr (Paul Siebeck): Tübingen.

Krieger, Tim (2001): "Intergenerational Redistribution and Labor Mobility: A Survey", FinanzArchiv 58, 339-361.

Homburg, Stefan and Wolfram Richter (1993): "Harmonizing Public Debt and Public Pension Schemes in the European Community", Journal of Economics Suppl. 7, 51-63.

Oates, Wallace E. (2001): "Fiscal Competition and European Union: Contrasting Perspectives", Regional Science and Urban Economics 31, 133-145.

Oates, Wallace E. (2002): "Fiscal and Regulatory Competition: Theory and Evidence", Perspektiven der Wirtschaftspolitik 3, 377-390.

OECD (2001): Trends in International Migration. Continuous Reporting System on Migration, Annual Report, Sopemi: Paris.

Richter, Wolfram (2002): "Social Security and Taxation of Labour Subject to Subsidiarity and Freedom of Movement", Swedish Economic Policy Review 9, 47-74.

Sinn, Hans-Werner (1990): "Tax Harmonisation and Tax Competition in Europe", European Economic Review 34, 489-504. 
Sinn, Hans-Werner (1997): "The Selection Principle and Market Failure in Systems Competition", Journal of Public Economics 66, 247-274.

Sinn, Hans-Werner (1998): "European Integration and the Future of the Welfare State", Swedish Economic Policy 5, 113-132.

Sinn, Hans-Werner (2000): "Pension Reform and Demographic Crisis. Why a Funded System is Needed and Why it is not Needed", International Tax and Public Finance 7, 389410 .

Sinn, Hans-Werner (2002): "EU Enlargement and the Future of the Welfare State", Scottish Journal of Political Economy 49, 104-115.

Sinn, Hans-Werner (2003): The New Systems Competition, Yrjö Jahnsson Lectures 1999, Basil Blackwell: Oxford and Malden, MA.

Thum, Claudio and Silke Uebelmesser (2003): "Mobility and the Role of Education as a Commitment Device”, International Tax and Public Finance 10, 549-564.

Uebelmesser, Silke (2003): The evolution of social policy issues on the European level, mimeo.

United Nations (2000): Replacement Migration: Is it a Solution to Declining and Aging Populations?, Working Paper (ESA/P) 160, United Nations: New York.

Wildasin, David E. (1991): "Income Redistribution in a Common Labor Market", American Economic Review 81, 757-774.

Wildasin, David E. (1994): "Income Redistribution and Migration”, Canadian Journal of Economics 27, 637-656.

Wildasin, David E. (1999): "Public Pensions in the EU: Migration Incentives and Impacts", in: Panagariya, Arvind et al. (eds): Environmental and Public Economics: Essays in Honor of Wallace E. Oates, Cheltenham (Elgar), 253-282.

Wildasin, David E. (2000): Factor Mobility and Fiscal Policy in the EU: Policy Issues and Analytical Approaches, CESifo Working Paper 344, Munich.

Wissenschaftlicher Beirat beim Bundesministerium der Finanzen (2001): Freizügigkeit und soziale Sicherheit, Bundesministerium der Finanzen, Bonn. 


\section{CESifo Working Paper Series}

(for full list see www.cesifo.de)

1044 Thomas Stratmann, Tainted Money? Contribution Limits and the Effectiveness of Campaign Spending, September 2003

1045 Marianna Grimaldi and Paul De Grauwe, Bubbling and Crashing Exchange Rates, September 2003

1046 Assar Lindbeck and Dennis J. Snower, The Firm as a Pool of Factor Complementarities, September 2003

1047 Volker Grossmann, Firm Size and Diversification: Asymmetric Multiproduct Firms under Cournot Competition, September 2003

1048 Dan Anderberg, Insiders, Outsiders, and the Underground Economy, October 2003

1049 Jose Apesteguia, Steffen Huck and Jörg Oechssler, Imitation - Theory and Experimental Evidence, October 2003

1050 G. Abío, G. Mahieu and C. Patxot, On the Optimality of PAYG Pension Systems in an Endogenous Fertility Setting, October 2003

1051 Carlos Fonseca Marinheiro, Output Smoothing in EMU and OECD: Can We Forego Government Contribution? A Risk Sharing Approach, October 2003

1052 Olivier Bargain and Nicolas Moreau, Is the Collective Model of Labor Supply Useful for Tax Policy Analysis? A Simulation Exercise, October 2003

1053 Michael Artis, Is there a European Business Cycle?, October 2003

1054 Martin R. West and Ludger Wößmann, Which School Systems Sort Weaker Students into Smaller Classes? International Evidence, October 2003

1055 Annette Alstadsaeter, Income Tax, Consumption Value of Education, and the Choice of Educational Type, October 2003

1056 Ansgar Belke and Ralph Setzer, Exchange Rate Volatility and Employment Growth: Empirical Evidence from the CEE Economies, October 2003

1057 Carsten Hefeker, Structural Reforms and the Enlargement of Monetary Union, October 2003

1058 Henning Bohn and Charles Stuart, Voting and Nonlinear Taxes in a Stylized Representative Democracy, October 2003 
1059 Philippe Choné, David le Blanc and Isabelle Robert-Bobée, Female Labor Supply and Child Care in France, October 2003

1060 V. Anton Muscatelli, Patrizio Tirelli and Carmine Trecroci, Fiscal and Monetary Policy Interactions: Empirical Evidence and Optimal Policy Using a Structural New Keynesian Model, October 2003

1061 Helmuth Cremer and Pierre Pestieau, Wealth Transfer Taxation: A Survey, October 2003

1062 Henning Bohn, Will Social Security and Medicare Remain Viable as the U.S. Population is Aging? An Update, October 2003

1063 James M. Malcomson, Health Service Gatekeepers, October 2003

1064 Jakob von Weizsäcker, The Hayek Pension: An efficient minimum pension to complement the welfare state, October 2003

1065 Joerg Baten, Creating Firms for a New Century: Determinants of Firm Creation around 1900, October 2003

1066 Christian Keuschnigg, Public Policy and Venture Capital Backed Innovation, October 2003

1067 Thomas von Ungern-Sternberg, State Intervention on the Market for Natural Damage Insurance in Europe, October 2003

1068 Mark V. Pauly, Time, Risk, Precommitment, and Adverse Selection in Competitive Insurance Markets, October 2003

1069 Wolfgang Ochel, Decentralising Wage Bargaining in Germany - A Way to Increase Employment?, November 2003

1070 Jay Pil Choi, Patent Pools and Cross-Licensing in the Shadow of Patent Litigation, November 2003

1071 Martin Peitz and Patrick Waelbroeck, Piracy of Digital Products: A Critical Review of the Economics Literature, November 2003

1072 George Economides, Jim Malley, Apostolis Philippopoulos, and Ulrich Woitek, Electoral Uncertainty, Fiscal Policies \& Growth: Theory and Evidence from Germany, the UK and the US, November 2003

1073 Robert S. Chirinko and Julie Ann Elston, Finance, Control, and Profitability: The Influence of German Banks, November 2003

1074 Wolfgang Eggert and Martin Kolmar, The Taxation of Financial Capital under Asymmetric Information and the Tax-Competition Paradox, November 2003

1075 Amihai Glazer, Vesa Kanniainen, and Panu Poutvaara, Income Taxes, Property Values, and Migration, November 2003 
1076 Jonas Agell, Why are Small Firms Different? Managers’ Views, November 2003

1077 Rafael Lalive, Social Interactions in Unemployment, November 2003

1078 Jean Pisani-Ferry, The Surprising French Employment Performance: What Lessons?, November 2003

1079 Josef Falkinger, Attention, Economies, November 2003

1080 Andreas Haufler and Michael Pflüger, Market Structure and the Taxation of International Trade, November 2003

1081 Jonas Agell and Helge Bennmarker, Endogenous Wage Rigidity, November 2003

1082 Fwu-Ranq Chang, On the Elasticities of Harvesting Rules, November 2003

1083 Lars P. Feld and Gebhard Kirchgässner, The Role of Direct Democracy in the European Union, November 2003

1084 Helge Berger, Jakob de Haan and Robert Inklaar, Restructuring the ECB, November 2003

1085 Lorenzo Forni and Raffaela Giordano, Employment in the Public Sector, November 2003

1086 Ann-Sofie Kolm and Birthe Larsen, Wages, Unemployment, and the Underground Economy, November 2003

1087 Lars P. Feld, Gebhard Kirchgässner, and Christoph A. Schaltegger, Decentralized Taxation and the Size of Government: Evidence from Swiss State and Local Governments, November 2003

1088 Arno Riedl and Frans van Winden, Input Versus Output Taxation in an Experimental International Economy, November 2003

1089 Nikolas Müller-Plantenberg, Japan’s Imbalance of Payments, November 2003

1090 Jan K. Brueckner, Transport Subsidies, System Choice, and Urban Sprawl, November 2003

1091 Herwig Immervoll and Cathal O'Donoghue, Employment Transitions in 13 European Countries. Levels, Distributions and Determining Factors of Net Replacement Rates, November 2003

1092 Nabil I. Al-Najjar, Luca Anderlini \& Leonardo Felli, Undescribable Events, November 2003

1093 Jakob de Haan, Helge Berger and David-Jan Jansen, The End of the Stability and Growth Pact?, December 2003 
1094 Christian Keuschnigg and Soren Bo Nielsen, Taxes and Venture Capital Support, December 2003

1095 Josse Delfgaauw and Robert Dur, From Public Monopsony to Competitive Market. More Efficiency but Higher Prices, December 2003

1096 Clemens Fuest and Thomas Hemmelgarn, Corporate Tax Policy, Foreign Firm Ownership and Thin Capitalization, December 2003

1097 Laszlo Goerke, Tax Progressivity and Tax Evasion, December 2003

1098 Luis H. B. Braido, Insurance and Incentives in Sharecropping, December 2003

1099 Josse Delfgaauw and Robert Dur, Signaling and Screening of Workers' Motivation, December 2003

1100 Ilko Naaborg,, Bert Scholtens, Jakob de Haan, Hanneke Bol and Ralph de Haas, How Important are Foreign Banks in the Financial Development of European Transition Countries?, December 2003

1101 Lawrence M. Kahn, Sports League Expansion and Economic Efficiency: Monopoly Can Enhance Consumer Welfare, December 2003

1102 Laszlo Goerke and Wolfgang Eggert, Fiscal Policy, Economic Integration and Unemployment, December 2003

1103 Nzinga Broussard, Ralph Chami and Gregory D. Hess, (Why) Do Self-Employed Parents Have More Children?, December 2003

1104 Christian Schultz, Information, Polarization and Delegation in Democracy, December 2003

1105 Daniel Haile, Abdolkarim Sadrieh and Harrie A. A. Verbon, Self-Serving Dictators and Economic Growth, December 2003

1106 Panu Poutvaara and Tuomas Takalo, Candidate Quality, December 2003

1107 Peter Friedrich, Joanna Gwiazda and Chang Woon Nam, Development of Local Public Finance in Europe, December 2003

1108 Silke Uebelmesser, Harmonisation of Old-Age Security Within the European Union, December 2003 